Revue européenne des sciences sociales

European Journal of Social Sciences

XLII-129 | 2004

La sociologie durkheimienne : tradition et actualité

\title{
Explication of a social fact: seasonal variation in the outbreak of insurrections
}

\section{Mark Traugott}

\section{(2) OpenEdition}

\section{Journals}

Édition électronique

URL : http://journals.openedition.org/ress/435

DOI : $10.4000 /$ ress.435

ISSN : $1663-4446$

Éditeur

Librairie Droz

Édition imprimée

Date de publication : 1 mars 2004

Pagination : 321-330

ISBN : 2-600-00941-8

ISSN : 0048-8046

Référence électronique

Mark Traugott, "Explication of a social fact: seasonal variation in the outbreak of insurrections », Revue européenne des sciences sociales [En ligne], XLII-129 | 2004, mis en ligne le 01 mars 2004 consulté le 04 mai 2019. URL : http://journals.openedition.org/ress/435; DOI : 10.4000/ress.435 


\title{
EXPLICATION OF A SOCIAL FACT : SEASONAL VARIATION IN THE OUTBREAK OF INSURRECTIONS
}

\author{
«If you wish to mature your thought, devote yourself to the \\ study of a great master; take a system apart, laying bare its \\ innermost secrets.»
}

(Émile Durkheim¹)

This oft-quoted advice from the great French sociologist was obviously taken to heart by Philippe Besnard and made his own. Though Durkheim remains best known for path-breaking substantive contributions to the study of human social groups, he was himself an inveterate student of the antecedents of sociological thought. Besnard's published work is similarly bifurcated. On the one hand, he established his position as one of the pre-eminent Durkheim scholars of our day both by making available to the scholarly community incisive commentary on the founder's seminal writings and by enlarging our understanding of Durkheim's perspective through the discovery and dissemination of a far-ranging body of academic and personal correspondence. On the other hand, Besnard sought to apply and extend the master's insights in empirical works of sociology that retain a distinctly Durkheimian flavor.

It is this second aspect of Besnard's scholarly production that I would like to address here. Though always graced with its author's own unique style, this work bears the unmistakable stamp of his mentor, for it typically aims at the identification and explication of social facts. These are, of course, the distinctive and irreducible properties of social groups that are made manifest as behaviors requiring the adoption of a group unit of analysis in order to reveal their true nature.

A prime instance is his exploration of naming practices, Un prénom pour toujours. ${ }^{2}$ There is a simple sociological elegance, reminiscent of Durkheim's classic works, to the book's choice of subject. Besnard and Desplanques exploit the commonplace presumption that the selection of a first name for one's flesh and blood (much like the resolve to take one's own life in the case of Suicide) is an intensely personal decision expressive of one's individual nature. In both cases, of course, the conceit that one's actions have a claim to uniqueness runs up against the observation that there are definite patterns, visible only at the level of the social group, that reveal these freely made individual choices to have been socially determined.

Durkheim's recommendation to René Maublanc is cited by Steven Lukes in Emile Durkheim : His Life and Work, New York: Harper and Row, 1977 at p. 54.

2 Philippe Besnard et Guy Desplanques, Un prénom pour toujours: la cote des prénoms, hier, aujourd' hui et demain. Paris: Balland, 1986. 
I am reminded of Besnard's inspired choice of topic each fall, when I inspect lists of students who have enrolled in my current classes. In the contemporary United States, the increased ethnic diversity is surely the most significant change that leaps to the attention of anyone who peruses these lists. But a closer examination reveals another striking trend: the parents of many of these students appear to have gone to extraordinary lengths to come up with variant and often eccentric spellings of even the most ordinary first names. It is as if they believed that orthographical creativity could somehow confer uniqueness and assure the realization of their most cherished hopes and aspirations for their offspring. Without the advantage of a group perspective - something that my class lists luckily afford me - they are unlikely to appreciate that to a sociological observer, the fact that their whimsy seems so general suggests not the exercise of individuality but the expression of a generational impulse that is social in its origins.

In just this way, Besnard has showed that the distribution of first names is highly patterned - is, in fact, subject to cycles whose definite peaks and troughs reveal that these choices are anything but individualistic acts. The impact of this demonstration is heightened by the contrast with our everyday understanding of naming practices as shaped by the idiosyncratic influences that impinge upon the lives of particular individuals. And when he makes the further point that the choice of a first name is actually guided by a sensitivity to status concerns or a desire for economic mobility, the deeply social origins of what we take to be purely personal choices are placed in sharp relief.

This is just one example of the strong Durkheimian bent in Besnard's substantive work, and not the one I want to focus on here. But before proceeding, I should recall to the reader's mind a few ideas that may hark back to some long-forgotten class in classical sociological theory, but will serve to introduce the empirical inquiry that is the nub of what this paper is about.

\section{THE SEARCH FOR SOCIAL FACTS}

Most sociologists are acquainted with Durkheim's famous dictum that social facts can be recognized by two salient properties: exteriority and constraint. He meant, of course, that they originate outside the individual (even though they may come to be internalized by properly socialized members of the group); and that they exert a compelling influence on individuals' actions (even if social actors are often unaware of how such forces shape their behavior.) These qualities were for Durkheim indicative of the power and ubiquity of the social dimension.

But Durkheim pointed to another, less obvious set of properties that are just as critical to the recognition of social facts: the simultaneous presence of a certain minimum of both patterning and variability. A case in point was the table of European statistics that was a focus of his argument in Suicide. It showed that while the rate of self-murder in any one country remained fairly stable over long periods of time, it varied significantly and consistently from one Continental nation to the next. It was the pairing of these observations that allowed him to introduce a remarkable change in perspective. After all, he reasoned, if there were no variability whatever in the suicide rate, it would effectively be a constant, and there would be nothing to explain. Conversely, a complete lack of patterning would 
amount to randomness - which also admits of no explanation and is, in fact, the standard we use to recognize the absence of any causal relationship. It is only when the social context imposes discernable patterns - which, however, differ from one group to the next - that we sense we are in the presence of a social fact.

The use of barricades in urban insurrections fulfills these requisites, though in a different way from suicide rates. When Besnard expressed an interest in data I had been compiling for a long-term project of research on European forms of contention, it was easy to see what attracted his attention. The incidence of barricade events over three hundred years of European history is highly uneven. A straightforward graph of the number of occurrences for each year from 1550 to 1900 would show a scattering of cases in the second half of the sixteenth and the first half of the seventeenth centuries, followed by their complete absence for well over a hundred years, and then their reappearance on the eve of the French Revolution. From there, the pace of this kind of insurrectionary activity would accelerate through the first half of the nineteenth century - a period that might well be termed «the age of barricades » - reaching a crescendo around the year 1848 .

Although the nineteenth century witnessed the adoption of this technique in other Continental nations, fully half of all the barricade events I have been able to identify took place in France. By their very nature, of course, the use of barricades was all but confined to urban areas, where narrow streets, concentrations of population, and the garrisoning of social control forces created the necessary preconditions for this type of confrontation. But one great city - the capital of France, where barricades were thought to have originated - accounted all unto itself for twenty-two of one hundred total events ${ }^{3}$. Indeed, through the first 218 years of their documented existence, barricades remained a predominantly Parisian and exclusively French custom. What these few summary statistics confirm is that, in spatial terms, the barricade was initially a uniquely Gallic innovation that underwent a process of rapid diffusion to other European countries over the course of the nineteenth century.

In chronological terms, barricade events have tended to cluster tightly into just a handful of cyclical peaks. Although instances where insurgents resorted to this technique of collective action might be considered moderately rare - barricades have, after all, materialized in just twenty-nine of the three hundred fifty years covered by my database - when they did make an appearance, it tended to be in substantial numbers. In truth, a mere six climactic periods of insurrectionary activity - concentrated within two years on either side of the crucial dates of 1588 , $1648,1789,1830,1848$, and 1871 - accounted for fully $75 \%$ of all European barricade events I have been able to catalog.

Much of this clumping can be attributed to a few mammoth insurrections that then precipitated a rash of successor events. The most noteworthy examples were the February and June Days of 1848, which helped spur dozens of subsequent outbreaks all across the Continent. As a result, my assertion that three-fourths of all such insurgency was confined to just six five-year spans between 1550 and 1900 greatly understates the proportion of all barricades that were constructed

The next closest contender was Lyon, where eight such events took place. The nearest foreign rival was Berlin, where four barricade events occurred, all between 1847 and 1849 . 
near these peaks, since most of the incidents that fell outside these clusters were isolated and small-scale events.

To yield a truer picture of the scope and significance of the uprisings with which barricades have been associated, it is helpful to assign weights to individual events based upon such considerations as the duration of the event; the number of participants involved; a tally of those killed, wounded, or arrested; or an actual count of how many barricades were erected. Unfortunately, the sources rarely furnish reliable information on all these variables, so I have had to make allowance for missing data by constructing a scale that classifies events as "small," "medium," "large," or "massive" according to an overall assessment of their magnitude 4 . By allocating scores to individual events based on a combination of these factors, it becomes possible to quantify the extent of barricaderelated activity in each calendar year. Because the resulting distribution of yearly totals is sharply skewed, it is helpful to chart these variations on a log scale (which eliminates years in which only a single, insignificant event occurred.) The resulting graph, in which the six major episodes of barricade construction stand out fairly clearly, is reproduced as Figure 1. Of course, it will not escape anyone with even a passing familiarity with French history from the early-modern period forward that the half dozen dates inserted on this chart to denote the apex of the six principal clusters are also the great landmarks of the insurrectionary tradition in France, which, since the sixteenth century, has been closely tied to the repertoire of barricade construction.

\section{SEASONALITY IN THE RECOURSE TO BARRICADES}

These considerations made barricade events a tempting subject for Besnard, who had a keen eye for the sort of regularity that betokens social facts. In his book on seasonal patterns, he plotted the number of barricade events - at least the total of thirty-one I had identified at that time - according to the month in which they began. The larger and somewhat richer sample of one hundred barricade events that I now have assembled may make it possible to confirm and even expand upon Besnard's initial analysis.

\footnotetext{
A small event (assigned a weight of one) normally began and ended on the same day, involved twenty or fewer insurgents, resulted in few if any casualties or arrests, and produced one to a few barricades. A medium event (assigned a weight of two) might extend over one or more days, but likely involved fewer than 100 participants, no more than ten of whom would typically be killed or wounded, and the construction of several to a dozen barricades. A large event (assigned a weight of three) generally lasted longer than a day, but involved no more than a thousand people and/or a hundred casualties, and generated from a dozen to a hundred barricades. Finally, a massive event (assigned a weight of four) usually lasted more than a day and engaged more than a thousand insurgents, at least one hundred of whom were killed or wounded, and the construction of at least one hundred (and in some cases as may as 2,000) barricades.

I have qualified these descriptions with terms like «generally» or «typically» because details were often lacking, the various criteria were sometime in conflict, and some indicators (for example, the number of arrests) applied only to a subset of all events (since insurgents are arrested only following unsuccessful uprisings.) In such cases, I had to use my best judgment to make ambiguous historical realities fit my ultimately arbitrary cut-off points.
} 


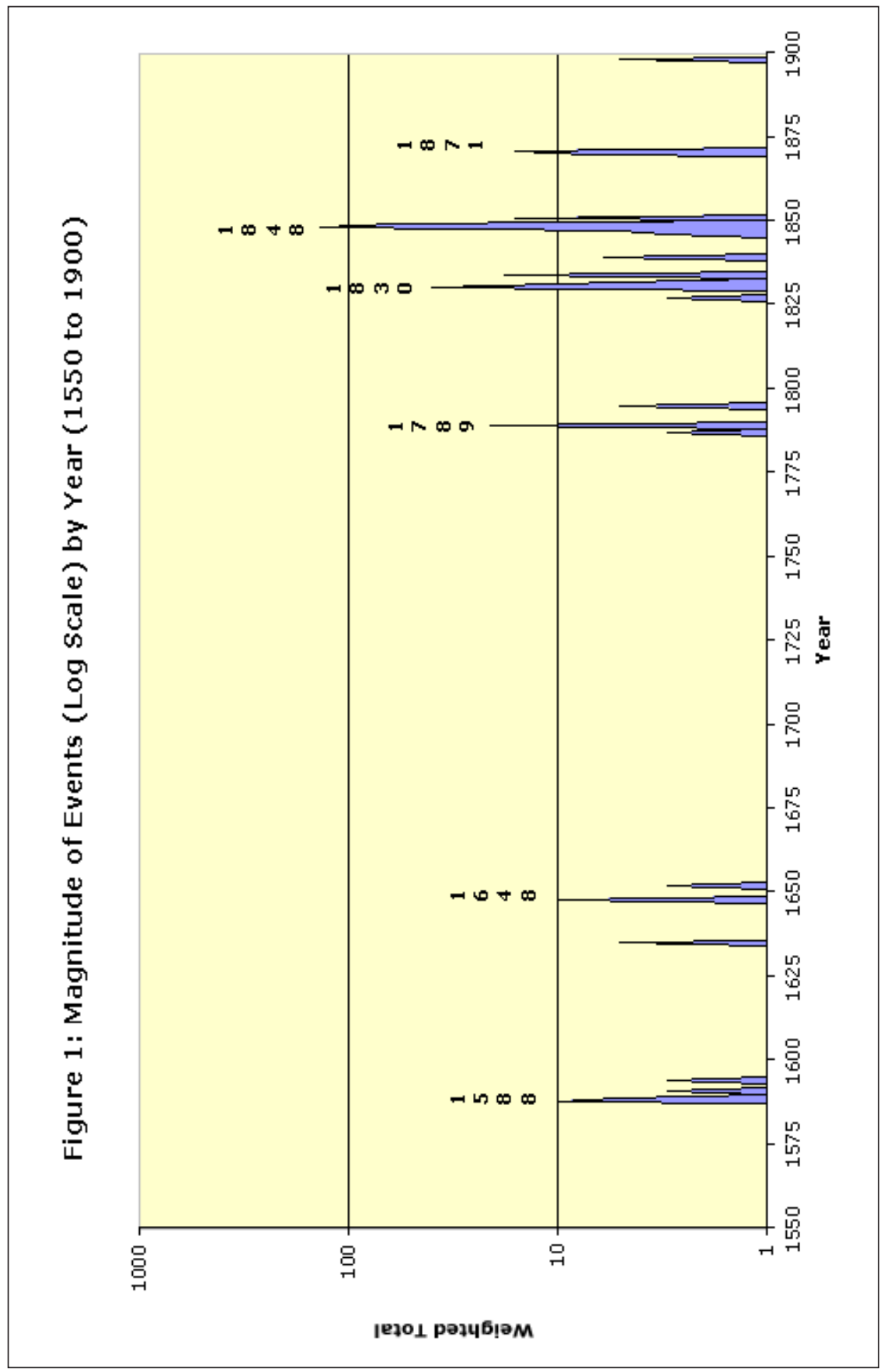


A simple frequency count of the number of events beginning in each month of the year is depicted in Figure 2. The earlier 31-event sample is represented by the lighter vertical bars in the front row; the updated 100-event sample corresponds to the darker set of vertical bars in the back row. Allowing for the difference in sample size, there is a rough correspondence in the distribution of events. Besnard's earlier description of a «spring peak» followed by a more modest «autumnal mound» holds up rather well in the newer data, although both crests have shifted a month or two earlier with the inclusion of additional data points.

Classic explanations for the genesis and timing of major insurrectionary outbursts have frequently taken cycles of agricultural and economic production as their point of departure. Among the best known examples in the Englishlanguage literature is George Rudé's study of the relationship between the timing of major journées during the French Revolution and the price of bread in Pariss. He showed that a good many (though by no means all) of the principal crowd events occurred at junctures when the cost of basic foodstuffs had recently spiked.

Although Ernest Labrousse never framed his observations in terms of seasonality, he offered an analysis of major insurrections that seems highly pertinent ${ }^{6}$. The outbreak of such events is related to economic disruptions of either of two types. New-style crises are characteristic of industrial economies and were therefore of minor importance during most of the period under scrutiny. Old-style crises were associated with a collapse of the agricultural sector, which continued to dominate the economies of France and most other European societies through much of the nineteenth century. It is this earlier pattern of disorder that mainly concerns us here.

The associations to which Rudé pointed - linking calamitous harvests, rising grain prices, and popular protest - make great intuitive sense. To this picture, Labrousse has added a model of how dislocation in the agricultural sector transmits and intensifies the hardships that are ultimately suffered by the urban working class. The mechanism works something like this : first, the need to import foreign grain at inflated prices depletes reserves of precious metals and creates a liquidity crisis. Lack of liquidity soon translates into a financial and credit crisis that hits the industrial sector especially hard and causes marginal enterprises to fail. Meanwhile, because so much larger a share of most people's disposable income must be allocated to the purchase of increasingly costly foodstuffs, demand for the goods produced by the urban economy is drastically reduced. Producers large and small are forced to make dramatic cutbacks in their work force, and an employment crisis quickly looms. Workers, caught between a rapidly rising cost of living and the inability to find jobs, are driven to desperation - with predictable consequences for the level of civil conflict.

See George Rudé, The Crowd in the French Revolution. London: Oxford University Press, 1967.

See Ernest Labrousse, «1848-1830-1789: comment naissent les revolutions,» pp. 1-29 in Comité français des sciences historiques, Actes du congrès historique du centenaire de la revolution de 1848, Paris: Presses Univérsitaires de France, 1948; and «Panoramas de la Crise,» pp. iii-xxiv in Ernest Labrousse, ed., Aspects de la crise et de la depression de l'économie française au milieu du 19e siècle, 1846-1851, La Roche-sur-Yon: Imprimerie Centrale de 1'Ouest, 1956. 


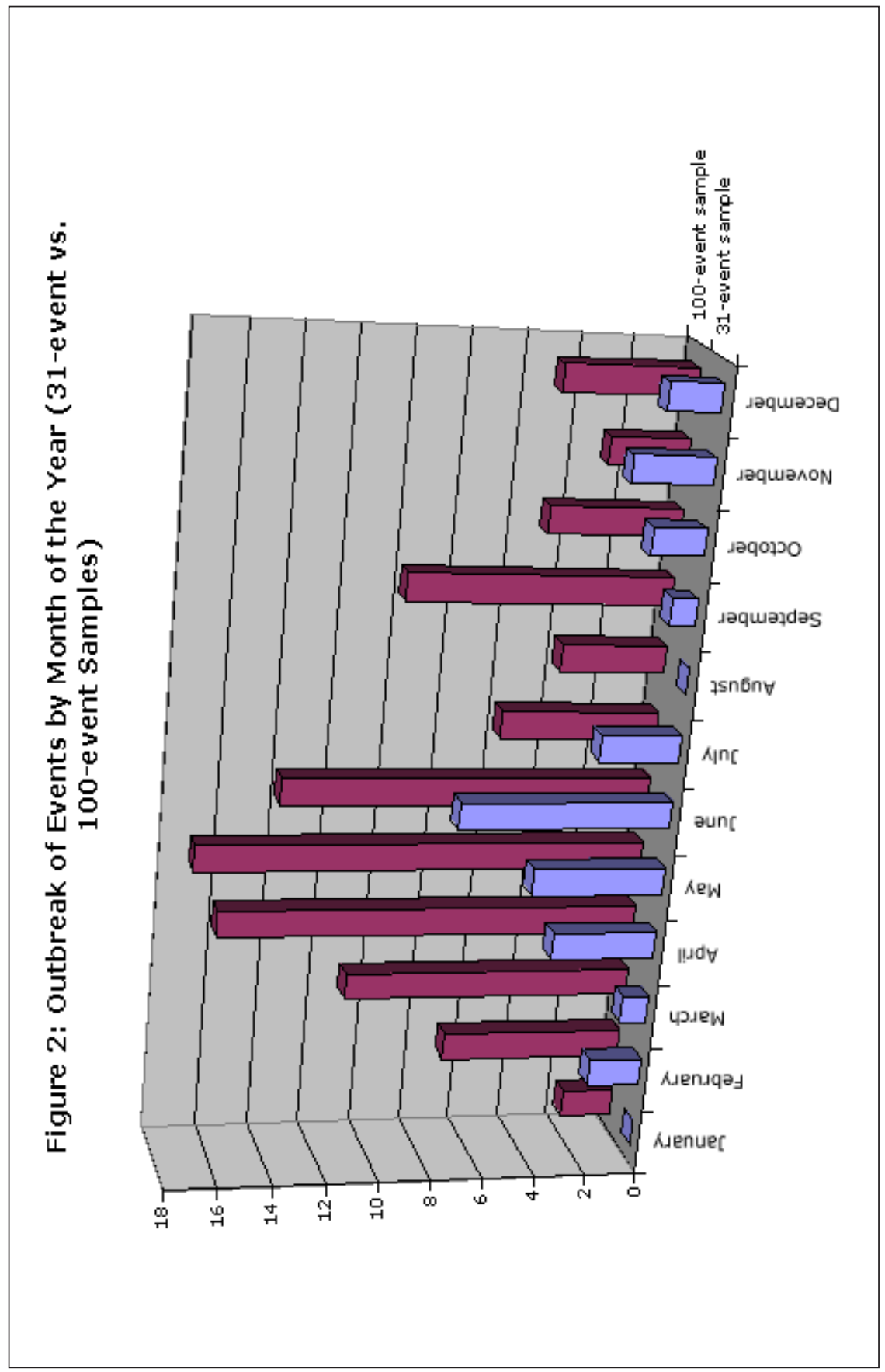


Do either of these models help explain the pattern observed in Figure 2? A definitive answer based on Rudé's work would probably require comparing levels of unrest with the price of bread compiled over a centuries-long period of time, an investigation that lies far beyond the scope of the modest exercise undertaken here. But Lefebvre's analysis, with its particular stress on a linked series of minicrises separated by lags of varying duration, is certainly suggestive. It helps us to understand why the primary concentration of events should occur in late spring or early summer, as meager stocks of grain are eventually exhausted (since the final months preceding the new harvest are always the hardest.) It may also help account for the lesser peak that follows a few months later, since the primary perturbations in the agrarian sector take some time to percolate into other areas of the economy and produce secondary shocks.

Labrousse makes it quite clear that the revolutions of 1848 still conformed to the standard old-style pattern of agriculture-driven crises ${ }^{7}$. But if he is correct about the shift that occurred in the etiology of insurrection as European economies underwent industrialization, then one might hope to catch a glimpse of a different configuration of forces in the second half of the nineteenth century. The limitations of my data set only permit me to compare events dating from before and after the year 1850 to see if any damping of the twin peaks in the monthly distribution of insurrections became evident as the century wore on ${ }^{8}$.

Unfortunately, the number of French events - arrayed in Figure 3 to show the earlier events in the back row, and the later ones in front - is too small and the resulting distribution too fragmentary to make a convincing case for such a change. Perhaps the progress of industrialization - a process that remained incomplete through the very end of the nineteenth century in France - was just too slow for its impact to show up before the turn of the new century. We also need to keep in mind that a maturing industrial economy effected changes in the fabric of society - notably the decline of the stratum of skilled artisans responsible for much of the revolutionary action with which barricades had been associated.

But there is another hypothesis that should be given serious consideration until a more satisfactory empirical test of the Labroussian proposition can be devised. In so far as the seasonality of pre-1850 events constituted a social fact - a property of the social group, rooted in everyday practices and common understandings - it might be expected to exhibit the sort of stubborn resistance to change that we associate with other culturally rooted phenomena. Labrousse is undoubtedly correct that new-style crises would eventually supplant the older pattern, but with a lag that the simple change in economic arrangements is unable to account for all on its own. The remarkable degree of continuity exhibited by the French in the

Whether one considers that the potato blight responsible for famine in cool-weather regions like Ireland converged with the ruinous wheat harvests that affected much of the rest of Europe in 1845 and 1846, there can be little doubt concerning the importance of agricultural crises in the genesis of the many uprisings of the late 1840s. Indeed, the simultaneity and scope of subsistence crises is obviously helpful in explaining the vast scale of revolutionary upheaval in 1848 .

$8 \quad$ Moreover, since my inventory of barricade events ends with the year 1900, I have confined this particular analysis to France, since in most other Continental nations the industrial transformation (and therefore the incidence of new-style crises) would have occurred still later. 


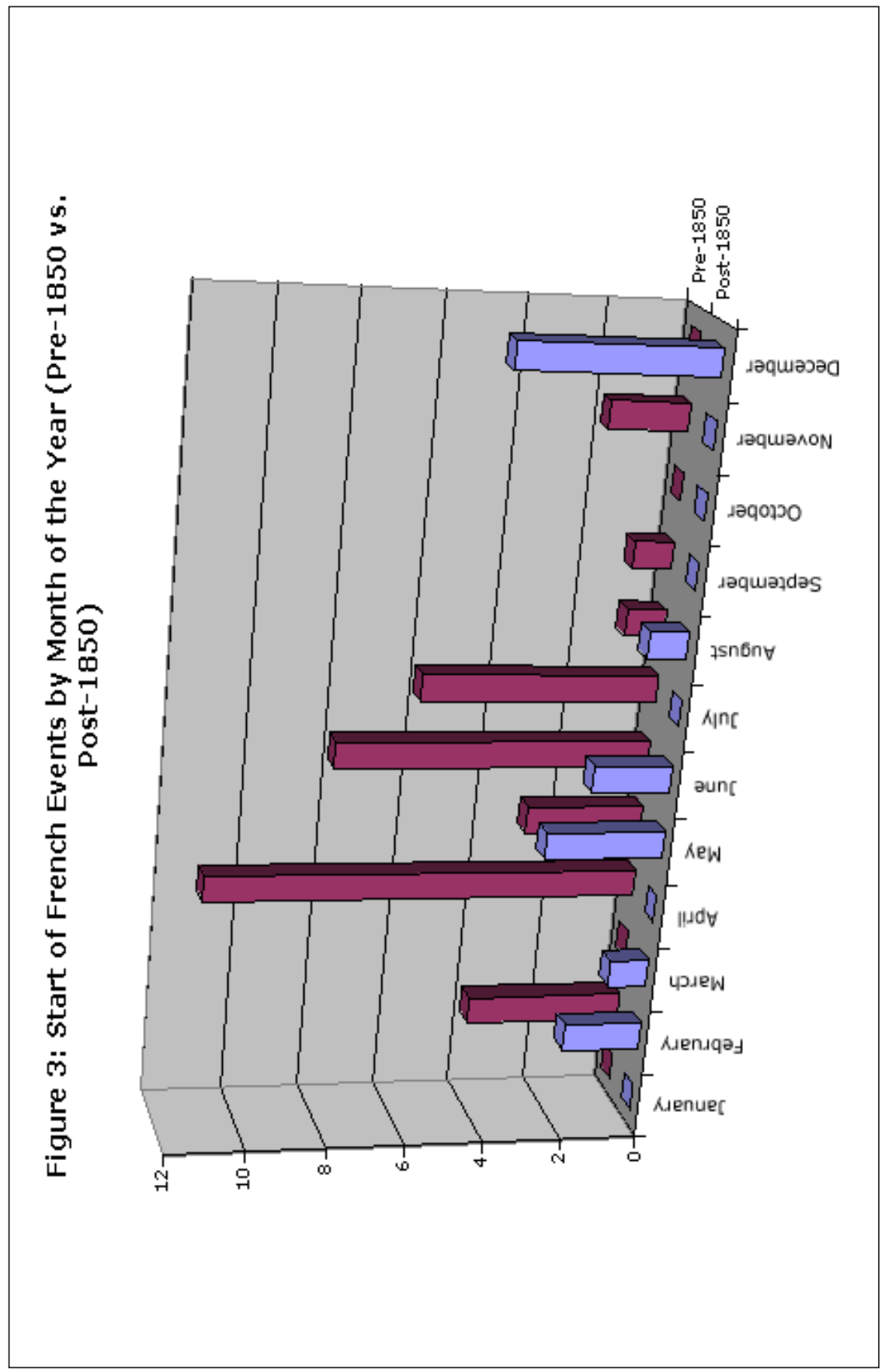


seasonality as well as the form of insurrectionary activity suggests the power and durability of group influences, a notion to which I suspect both Durkheim and Besnard would readily have subscribed.

Department of History

UC Santa Cruz, USA

traugott@ucsc.edu 